\title{
Effect of Training and Work Discipline on Employee Performance PT PLN (Persero) Power Plants Control Unit Keramasan
}

\author{
Rochman Jalil, Badia Perizade, Marlina Widiyanti
}

\begin{abstract}
This study aims to determine the effect of Training and Work Discipline on the Performance of Employees of PT PLN (Persero) Power Plants Control Unit Keramasan. The method used in obtaining data is by using a questionnaire given to 111 employees from 153 employees as respondents. Data has been analyzed using multiple linear regression analysis. The results show that training partially has a positive and significant influence on employee performance, work discipline partially has a positive and significant influence on employee performance, and training and work discipline simultaneously have a positive and significant influence on employee performance.
\end{abstract}

Keywords: Training, Work Discipline, and Employee Performance

\section{INTRODUCTION}

In the era of globalization, competition between organizations is getting tougher. An organization needs professional human resources and has good performance. This is to maintain the sustainability of the organization's business processes. Therefore, organizations need to pay attention to the condition of human resources in the organization. Human resource management is a design to regulate the role of resources owned by each individual effectively and efficiently. This is so that it can be used maximally to achieve organizational goals. According to Byars and Rue [1], human resources is a system of activities and strategies that focus on the success of managing employees at all levels of an organization to achieve organizational goals. One of the organizational efforts in increasing competitiveness is by making employee performance a goal. Human resources are valuable assets. Basically, organizations need employees who have high performance [2]. During the 2016-2018 period there was a decrease in the achievement of employee performance. In 2016 and 2017, employee performance exceeded the target,

Manuscript received on June 15, 2019.

Revised Manuscript received on June 25, 2019.

Manuscript published on July 30, 2019.

* Correspondence Author

Rochman Jalil*, (Corresponding Author), Candidate Master of Management in Magister Management University of Sriwijaya, Indonesia.

Prof. Hj. Badia Perizade, MBA., Ph.D Lectures in Faculty Economic University of Sriwijaya, Indonesia.

Hj. Marlina Widiyanti, S.E., S.H., M.M., Ph.D., Lectures in Faculty Economic University of Sriwijaya, Indonesia.

(C) The Authors. Published by Blue Eyes Intelligence Engineering and Sciences Publication (BEIESP). This is an open access article under the CC BY-NC-ND license (http://creativecommons.org/licenses/by-nc-nd/4.0/) although it tended to decrease in realization. Whereas in 2018, employee performance does not reach the target. in 2017 the percentage of participants who did not take ITN training was $61.4 \%$, while LNA training was 86.3\%. In 2018 there was an increase in training participants compared to 2017. According to researchers, data on employee participation in 2017 training could have an effect on employee performance the following year [3]. During 2018 there were 21 cases of employees entering the entry categories of 1-7 times per month, entry categories 8-15 times per month as many as 283 , and entry categories $>16$ times per month as many as 1555 cases. Employees do not enter due to frequent leave, permission, and without information, thus affecting the number of attendances for a year [4]. Based on the above phenomena, the researcher wants to analyze and prove the effect of training on employee performance, analyze and prove the effect of discipline on employee performance, and analyze and prove the effect of training and work discipline on the performance of PT. PLN (Persero) Power Plants Control Unit Keramasan."

\section{LITERATURE REVIEW}

\section{A. Training}

According to Veithzal [5], training is part of education which includes the process of study in order to improve work skills outside the education system in a short period of time with methods that prioritize practice rather than theory. Therefore, training is considered important by both long-time employees and new employees.

Dessler [6] has stated that training is a learning process that employees need to carry out a job. Whereas according to Mondy [7], training and development are at the heart of the organization's ongoing efforts to improve employee competency and performance.

\section{B. Work Discipline}

Work discipline is one of the operative functions of human resource management that describes the amount of employees' sense of responsibility towards the tasks that have been given to him [8]. Whereas according to Rivai [9], work discipline is "a tool used by managers to change behavior and efforts to increase awareness and willingness of employees to comply with all company regulations and social norms that apply in the company". While Sutrisno [10] has explained that discipline is an attitude of willingness and willingness of an individual to obey the rules that apply in their environment.

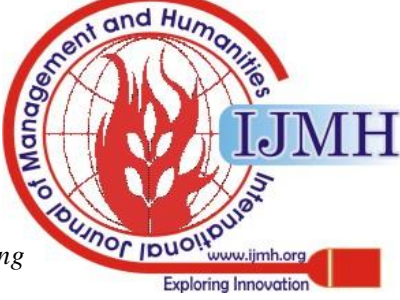




\section{Effect of Training and Work Discipline on Employee Performance PT PLN (Persero) Power Plants Control Unit Keramasan}

The attitude of work discipline is an important thing for a company in realizing its ideals. The absence of good work discipline implementation will make it difficult for companies to achieve desired results. The discipline of an employee shows a great sense of responsibility for the work and obligations that have been given to him.

So it can be concluded that the work discipline is an attitude or behavior of an employee, such as obedience or compliance with the applicable rules and regulations in the company.

\section{Employee Performance}

Gomes [11] states that performance is a record of the results of the functions of an employee's work or activity for a certain period of time. While according to Mangkunegara [12] has explained that performance is an output of work both in quantity and quality that has been obtained by an employee according to the portion that has been given by the organization. Therefore, the performance of an employee can be measured through work results or work performance results in a certain period of time.

\section{RESEARCH METHODS}

This study discusses the effect of training and work discipline on employee performance at PT. PLN (Persero) Power Plants Control Unit Keramasan. This study analyzes whether the training variables and work discipline affect the performance of employees at PT. PLN (Persero) Power Plants Control Unit Keramasan positively and significantly or not. The number of employees in this unit amounted to 153 employees divided by several divisions, including: maintenance division, operations division, finance division, human resources division, administration division, and engineering division. The number of respondents used in this study which was calculated using the Slovin formula was 111 samples. The application of this study will regress the independent variables namely Training $\left(\mathrm{X}_{1}\right)$ and Work Discipline $\left(\mathrm{X}_{2}\right)$ on the dependent variable namely Employee Performance (Y). To find the magnitude of $\mathrm{X}_{1}$ and $\mathrm{X}_{2}$ together, multiple linear regression methods are used.

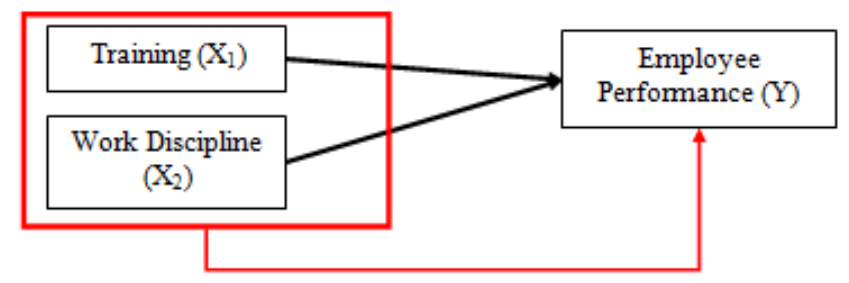

Figure 1. Theoretical Framework

\section{Research Hypothesis}

The research hypothesis can form as follows:

H1. Training has a positive and significant effect on employee performance at PT. PLN (Persero) Power Plants Control Unit Keramasan.

H2. Work Discipline has a positive and significant effect on employee performance at PT. PLN (Persero) Power Plants Control Unit Keramasan.

H3. Training and work discipline have a positive and significant effect simultaneously on employee performance at PT. PLN (Persero) Power Plants Control Unit Keramasan.

\section{Data Analysis Techniques}

$=$ employee performance

$=$ training

$=$ work discipline

$=$ constant

$=$ training regression coefficient

$=$ work discipline regression coefficient

$=$ error

\section{Description of research variables}

The results of the respondents 'description of responses to training variables have a percentage of respondents' score of $83.8 \%$. The response score is classified as $68.01 \%-84.00 \%$, thus indicating that the training of employees of PT PLN (Persero) Power Plants Control Unit Keramasan is considered good or high. This states that the employee may feel satisfied with the training that has been carried out. In accordance with Dessler's theory [6], which states that training is a process of learning skills needed by employees to do their jobs. Therefore, training is considered important by employees who have either worked for a long time or are new employees. This also shows that training is an important matter to be considered by PT PLN (Persero) Power Plants Control Unit Keramasan. The results of the respondent's description of responses to the work discipline variable have a percentage of respondents' scores of $77.5 \%$. When compared with the classification score of the response score, the work discipline variable is at a score of $68.01 \%-84.00 \%$. this shows that work discipline is an important matter to be considered by PT PLN (Persero) Power Plants Control Unit Keramasan. The results of the respondent's description of employee performance variables have an average percentage of $77.5 \%$. Based on the interval value table, the employee performance variables enter into the intervals of $68.01 \%$ $84.00 \%$. This shows that employee performance variables become things that need to be given attention by PT PLN (Persero) Power Plants Control Unit Keramasan.

\section{Validity and Reliability Test}

Test the validity of the questionnaire through a comparison of the results of $r$ count on each result of the statement item with the value of $r$ table. the results of the validity test on the questionnaire of this study are training variables, work discipline, and employee performance have $r$ count value $>r$ table (0.1865). So, it can be said that all items used in this study are valid. Based on table 1 below, it explains that the item statement of variables used in this study has Cronbach Alpha value > 0.6, so it can be said that the data on these variables are declared as reliable as instruments. 
Table 1 Reliability Test Results

\begin{tabular}{lcc}
\hline \multicolumn{1}{c}{ Variable } & $\begin{array}{l}\text { Cronbach Alpha } \\
\text { and the criteria }\end{array}$ & $\begin{array}{l}\text { Reliability } \\
\text { Test Results }\end{array}$ \\
\hline $\begin{array}{l}\text { Training }\left(\mathrm{X}_{1}\right) \\
\text { Work }\end{array}$ & $0,949>0,6$ & Reliable \\
$\begin{array}{l}\text { Discipline } \\
\left(\mathrm{X}_{2}\right)\end{array}$ & $0,792>0,6$ & Reliable \\
$\begin{array}{l}\text { Employee } \\
\text { Performance } \\
(Y)\end{array}$ & $0,968>0,6$ & Reliable \\
\hline
\end{tabular}

Source : Data processing results, 2019

Classical Test Assumptions

Normality Test

Table 2. Kolmogorov-Smirnov Test

\begin{tabular}{lcr}
\hline & & $\begin{array}{c}\text { Unstandardized } \\
\text { Residual }\end{array}$ \\
\hline $\mathbf{N}$ & $\begin{array}{r}111 \\
\text { Normal Parameters }{ }^{\text {a,b }}\end{array}$ & $\begin{array}{c}\text { Mean } \\
\text { Std. } \\
\text { Deviation }\end{array}$ \\
$\begin{array}{l}\text { Most Extreme } \\
\text { Differences }\end{array}$ & Absolute & 4,28928802 \\
& Positive & 0,094 \\
& Negative & 0,094 \\
Kolmogorov-Smirno & & $-0,091$ \\
$\mathbf{v}$ Z & & 0,993 \\
$\begin{array}{l}\text { Asymp. Sig. } \\
\text { (2-tailed) }\end{array}$ & & 0,278 \\
\hline Source $:$ Dat processing & & \\
\hline
\end{tabular}

Based on table 2 above, it shows that there is a residual value or value of Asymp. Sig (2-tailed) of 0.278 where greater than the value of 0.05 . So the conclusion of the test results above shows that the distribution function of the survey results can be said to be normally distributed.

\section{Multicollinearity Test}

Table 3. Collinearity Statistics

\begin{tabular}{lll}
\hline Variable & Tolerance & VIF \\
\hline Training $\left(\mathbf{X}_{1}\right)$ & 0,884 & 1,131 \\
Work Discipline & 0,884 & 1,131 \\
$\left(\mathbf{X}_{2}\right)$ &
\end{tabular}

Source :Data processing results, 2019

Based on table 3 above it can be seen that the VIF value is 1.131 for training variables and work discipline. These results can be concluded that the independent variables in this study are free from the symptoms of multicollinearity $(1,131$ $<10)$.

\section{Heteroscedasticity Test}

Based on Figure 2 below, it shows that the results of this study have a scatterplot pattern with scattered points above and below zero and no clear pattern. So the results of this study can be stated that there is no heteroscedasticity.
Source :Data processing results, 2019

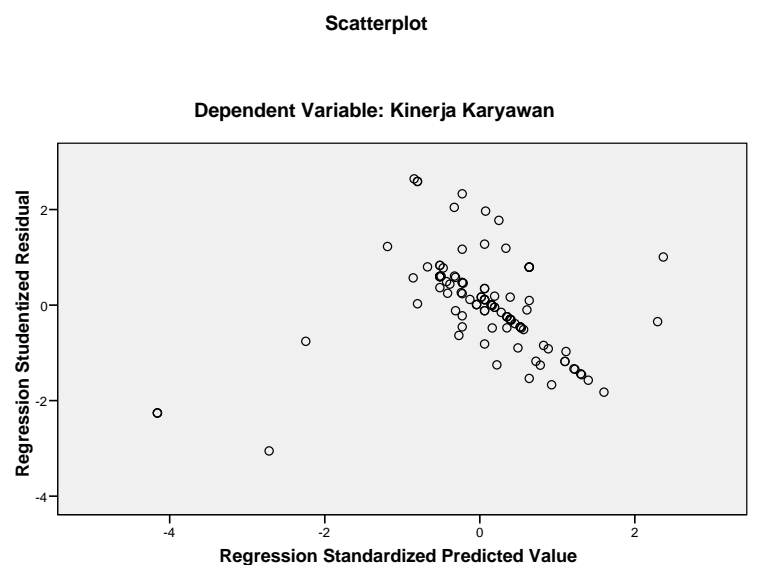

Figure 2 Heterocedasticity test results

\section{Multiple Linear Regression Analysis}

Multiple linear regression testing is done to see the effect of training variables and work discipline on employee performance. Based on the results of the test, the results obtained are as shown in the table below:

Table 4 Results of multiple linear regression analysis

\begin{tabular}{lccc}
\hline Variable & (B) & $\begin{array}{c}\text { Std } \\
\text { Error }\end{array}$ & Beta \\
\hline Constant & 4,031 & 4,748 & \\
Training (X) & 0,23 & 0,082 & 0,18 \\
Work Discipline & 1,542 & 0,141 & 0,7 \\
\hline $\left.\mathbf{X}_{2}\right)$ & & \\
\hline
\end{tabular}

Source : Data processing results, 2019

A constant with a value of 4.031 means that if training and work discipline are zero, then the value of employee performance is 4.031 .

Training regression coefficient with a value of 0.23 means that training affects employee performance worth 0.23 . If training increases $1 \%$, it will increase employee performance by 0.23 .

The work discipline regression coefficient with a value of 1.542 means that work discipline affects employee performance with a value of 1.542. If work discipline increase by $1 \%$, it will increase employee performance by 1,542 .

Based on the results of table 4 above, the variables that have the dominant effect are work discipline of 1.542 while the training variable is only 0.23 .

The Correlation Coefficient (r) and Determination $\left(\mathbf{R}^{2}\right)$ Test

Table 5 Test results of the correlation coefficient and determination

\begin{tabular}{ccccc}
\hline $\mathbf{r}$ & $\begin{array}{c}\boldsymbol{R} \\
\text { Square }\end{array}$ & $\begin{array}{c}\text { Adjusted } \\
\boldsymbol{R} \text { Square }\end{array}$ & $\begin{array}{c}\text { Std. Error } \\
\text { of } \\
\text { the } \\
\text { Estimate }\end{array}$ & $\begin{array}{c}\text { Durbin- } \\
\text { Watson }\end{array}$ \\
\hline $0,780^{\mathrm{a}}$ & 0,609 & 0,601 & 4,329 & 2 \\
\hline
\end{tabular}

Source : Data processing results, 2019 


\section{Effect of Training and Work Discipline on Employee Performance PT PLN (Persero) Power Plants Control Unit Keramasan}

Based on table 5 above, the value of the correlation coefficient ( $r$ ) has a value of 0.780 . It can be concluded that there is a very close relationship between fellow variables (entered in the range of 0.71-0.90). While the coefficient of determination has a value of 0.609 (60.9\%). This can be stated that the training variable and work discipline can explain the performance of employees with a value of $60.9 \%$, while the remaining $39.1 \%$ is influenced by independent variables apart from the variables of this study.

\section{Hypothesis Test Results}

\section{Significance Test t (Partial)}

Significance testing $t$ in this study aims to determine how far the influence of independent variables individually on the dependent variable. This study was conducted with a significance of $0.05(\alpha=5 \%)$.

Table 6 Test results $t$

\begin{tabular}{cccccc}
\hline Model & \multicolumn{2}{c}{$\begin{array}{c}\text { Unstandardized } \\
\text { Coefficients }\end{array}$} & $\begin{array}{c}\text { Standardized } \\
\text { Coefficients }\end{array}$ & t & Sig. \\
& B & $\begin{array}{c}\text { Std. } \\
\text { Error }\end{array}$ & Beta & & \\
\hline Constant & 4,031 & 4,748 & & 0,849 & 0,398 \\
$\begin{array}{c}\text { Training } \\
\left(\mathrm{X}_{1}\right)\end{array}$ & 0,230 & 0,082 & 0,180 & 2,808 & 0,006 \\
$\quad$ Work & & & & & \\
$\begin{array}{c}\text { Discipline } \\
\left(\mathrm{X}_{2}\right)\end{array}$ & 1,542 & 0,141 & 0,700 & 10,94 & 0,000 \\
\hline
\end{tabular}

Source : Data processing results, 2019

Based on the data in table 6 above, the $t$ value of the training variable is obtained at 2.808, while the work discipline has a $\mathrm{t}$ value of 10.940 . This study has a significance level of $5 \%(\alpha=0.05)$ with the value of Degree of Freedom $(\mathrm{df})=\mathrm{nk}=111-3=108$. Based on the value of $\mathrm{df}$ $=108$ with significance of 0.05 , the table value for this research data is obtained. is 1.98217 . The results of the analysis can be explained as follows: (1). The value of the training count is greater than $\mathrm{t}$ table, which is $2.808>1.98217$ and the significance value is smaller than 0.05 , which is 0.006 $<0.05$. A positive $t$ value indicates that training has an influence in line with employee performance. So this explains the training has a positive and significant effect on employee performance at PT PLN (Persero) Power Plants Control Unit Keramasan. (2). The value of work discipline count $\mathrm{t}$ is greater than $\mathrm{t}$ table, which is $10,940>1,98217$ and the significance value is smaller than 0,05 which is $0,000<$ 0,05 . A positive $t$ value indicates that work discipline has a direct influence on employee performance. So these results indicate that the work discipline variables have a positive and significant effect on employee performance variables at PT PLN (Persero) Power Plants Control Unit Keramasan.

\section{F Significance Test}

Based on the results of testing and processing data with SPSS, the obtained F test results (simultaneous) data include:

\begin{tabular}{cccccc}
\hline & $\begin{array}{c}\text { Sum of } \\
\text { Squares }\end{array}$ & df & $\begin{array}{c}\text { Mean } \\
\text { Square }\end{array}$ & F & Sig. \\
\hline Regression & 3148,617 & 2 & 1574,309 & 84 &, $000^{\text {a }}$ \\
Residual & 2023,779 & 108 & 18,739 & & \\
Total & $\mathbf{5 1 7 , 3 9 6}$ & $\mathbf{1 1 0}$ & & & \\
\hline
\end{tabular}

Source : Data processing results, 2019
In this study, first must know the value of $\mathrm{F}$ table. $\mathrm{F}$ table is determined with a significance level of $5 \%$ and with the value of Degree of Freedom $(\mathrm{df} 1)=\mathrm{k}-1=2$ and $\mathrm{df} 2=\mathrm{n}-\mathrm{k}=$ 108 . Based on the values of $\mathrm{df} 1=2$ and $\mathrm{df} 2=108$, then the $\mathrm{f}$ table value is 3,08 . Based on the results of the $F$ test in table 4.12 the value of $f$ count $>f$ table is $84.014>3.08$. This shows that there is a significant simultaneous effect of training and work discipline on employee performance.

\section{DISCUSSION}

Based on the results of the above analysis stated that training has a positive and significant effect on employee performance. This is proven by the value of $t$ count $>t$ table with a value of $2.808>1.98217$ and the Sig value is smaller than 0.05 , which is $0.006<0.05$. So it can be concluded that the first hypothesis (H1) is accepted.

The above conclusion is supported by Robbins [13], which states that training programs can improve the effectiveness of an employee. Self-effectiveness in question is a strong expectation that employees have to carry out in new situations and are willing to mobilize to complete tasks well and influence employee performance. The above conclusions are also supported by previous researchers, namely Halawi [14], Motlokoa [15], Afroz [16], Raza [17], Anitha [18], Al-Mzary [19], and Iqbal [20] which explain training has a positive and significant influence on employee performance.

From the results above, it is necessary for management to pay serious attention to the training provided by employees. Management is advised to frequently evaluate the training conducted. The evaluation was carried out by measuring the reactions of trainees, conducting examinations to participants after being given training material, interviewing participants and coworkers to gain influence on the level of behavior, and comparing the work results of participants before and after training. Based on the results of the above analysis states that work discipline has a positive and significant effect on employee performance. These results are evidenced by the value of $\mathrm{t}$ count $>\mathrm{t}$ table, which is $10,940>1,98217$ and the significance value is smaller than 0,05 which is $0,000<0,05$. So it can be concluded that the first hypothesis (H2) is accepted. The above conclusion is supported by Mathis [8], which states that work discipline is one of the operative functions of the management of human resources that illustrates the amount of employee responsibility for the assigned task. If someone has a big responsibility, then the performance will be good. The above conclusion is also supported by previous researchers namely Simatupang [21], Arifin [22], Suyitno [23], Hartato [24], and Roeleejanto[25], which states that work discipline has a positive and significant influence on employee performance.

From the results above, it is necessary for management to pay serious attention to the work discipline of employees in the company. There are several things that must be considered in order to maintain employee performance, namely by paying attention to the presence of employees in carrying out their duties and obligations, the level of activity is completed at a predetermined time, and an attitude of obedient employees and willing to implement the rules.

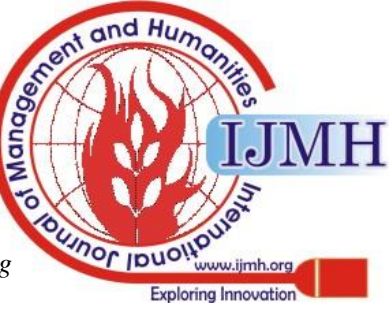


Based on multiple linear regression analysis that has been done in this research, there are results where the variable that has a dominant influence is work discipline worth 1.542 while the training variable is only 0.23 . In the results of the research test, the $\mathrm{F}$ test obtained $\mathrm{f}$ count $>\mathrm{f}$ table $(84,014>$ $3,08)$ and sig value $<0,005(0,000<0,005)$. This result states that there is a significant simultaneous influence of training and work discipline on the performance of employees of PT PLN (Persero) Power Plants Control Unit Keramasan.

\section{CONCLUSION AND RECOMMENDATIONS}

\section{Conclusion}

From the results of the analysis and discussion of the results of this study, the research conclusions can be taken as follows:

1. Training has a positive and significant influence on the performance of employees of PT. PLN (Persero) Power Plants Control Unit Keramasan.

2. Work discipline has a positive and significant influence on the performance of employees of PT. PLN (Persero) Power Plants Control Unit Keramasan.

3. Training and work discipline simultaneously have a positive and significant influence on the performance of employees of PT. PLN (Persero) Power Plants Control Unit Keramasan. The variable that has the most dominant influence is the work discipline variable compared to the training variable.

\section{Recommendations}

Based on the conclusions expressed by the researcher above, then the suggestions given through this study include:

1. To improve performance in terms of training, management is advised to frequently evaluate training conducted. The evaluation was carried out by measuring the reactions of trainees, conducting examinations to participants after being given training material, interviewing participants and coworkers to gain influence on the level of behavior, and comparing the work results of participants before and after training.

2. The management pays attention to the presence of employees in carrying out their obligations and responsibilities, the level of work completed at a predetermined time, and the obedient attitude of employees and is willing to implement the rules.

3. For the next researcher, it is expected to add variables and other research indicators, so that they can answer in more detail in explaining research on employee performance

\section{REFERENCES}

1. Byars, L., and Rue, L., 2006. Human resource management, 8th edition. New York, NY: McGraw-Hill, pp. 371-383.

2. Douglas, G. 2000. Manajemen Kas, Jakarta: PT. Pusataka Binaman Pressindo.

3. Annual Report. 2017. PT. PLN UPDK Keramasan. Palembang.

4. Annual Report. 2018. PT. PLN UPDK Keramasan. Palembang.

5. Veithzal, Ramly, Thoby, Willy. 2014. Manajemen Sumber Daya Manusia, edisi ketiga, Rajawali Pers.

6. Dessler, Gary. 2010. Manajemen Sumber Daya Manusia (edisi kesepuluh). Jakarta Barat: PT Indeks

7. Mondy R Wayne. 2008. Manajemen Sumber Daya Manusia. Jakarta: Erlangga.

8. Mathis, R.L. and Jackson, J.H. 2003. Human Resource Management. Australia, Sydney:Thomson South Western.
9. Rivai, Veithzal. 2011, Manajemen Sumber Daya Manusia untuk Perusahaan: dari Teori ke Praktik, Jakarta: Raja Grafindo Persada.

10. Edy Sutrisno. 2016. Manajemen Sumber Daya Manusia. Cetakan ke-8. Jakarta : Prenada Media Group.

11. Gomes, C. Faustino. 2010. Manajemen Sumber Daya Manusia Yogyakarta: Andi Offset.

12. A.A. Anwar Prabu Mangkunegara. 2009. Manajemen Sumber Daya Manusia. Bandung: PT. Remaja Rosdakarya.

13. Robbins, Stephen. Judge, Timothy. 2015. Perilaku Organisasi. Edisi 16. Jakarta: Salemba Empat.

14. Halawi, A., dan Haydar, N. 2018. "Effects of Training on Employee Performance: A Case Study of Bonjus and Khatib \& Alami Companies". International Humanities Studies, 5(2), 2311-7796.

15. Motlokoa, M. E., Sekantsi, L. P., dan Monyoloc, R. P. 2018. "The Impact of Training on Employees' Performance: The Case of Banking Sector in Lesotho". International Journal of Human Resource Studies , 8(2), 2162-3058.

16. Afroz, N. N. 2018. "Effects of Training on Employee Performance - A Study on Banking Sector, Tangail Banglades". Global Journal of Economics and Business, 4(1), $111-124$.

17. Raza, K., Afridi, F. K., dan Khan, S. I. 2017. "Impact of Training on Employees Performance and Job Satisfaction: An Empirical Study of Plastic Industry of Hayatabad Industrial Estate". Journal of Business and Tourism, 3(1), $2520-0739$.

18. Anitha, R., dan Kumar, M. A. 2016. "A Study on the Impact of Training on Employee Performance in Private Insurance Sector, Coimbatore District". International Journal of Management Research \& Review, 6(10), 2249-7196.

19. Al-Mzary, M. M. M., Al-Rifai, A. D. A., dan Al-Momany, M. O. E. 2015. "Training and its Impact on the Performance of Employees at Jordanian Universities from the Perspective of Employees: The Case of Yarmouk University". Journal of Education and Practice, 6(32), 2222-1735.

20. Iqbal, N., Ahmad, N., dan Javaid, K. 2014. "Impact of Training on Employee Performance in The context of Telecommunication sector of D. G. Khan, (Pakistan)"'. International Letters of Social and Humanistic Sciences, 17, 60-73.

21. Simatupang, A. C., dan Saroyeni, P. 2018."The Effect of Discipline, Motivation and Commitment to Employee Performance". Journal of Business and Managemen, 20(6), 31-37.

22. Arifin, A. H., Sullaida., dan Nurmala. 2018. "The Relationship Of Job Satisfaction,Transformational Leadership, And Work Discipline On Performance Employee With Organizational Commitment As Intervening Variable Of Administration Staffs At State Malikussaleh University". Indonesian Journal of Educational Review, 5(1), 52-67.

23. Suyitno. 2017. "Effect of Competence, Satisfaction and Discipline on Performance of Employees in the Office of Women Empowerment and Family Planning of West Papua”. Asian Social Science, 13(5), 1911-202.

24. Hartato, O. 2016. "Influence Motivation, Ability, and Discipline On Performace Employee Department Sales and Marketing PT Pionirbeton Industry Jakarta". Jurnal Riset Manajemen Sains Indonesia, 7(1).

25. Roeleejanto, C., Brasit, N., Payangan, O. R., dan Pahlevi, C. 2015. "Effects of Leadership, Competency, and Work Discipline on the Application of Total Quality Management and Employees' Performance for the Accreditation Status Achievement of Government Hospitals in Jakarta, Indonesia". Scientific Research Journal, 3(11) 2201-2796.

\section{AUTHORS PROFILE}

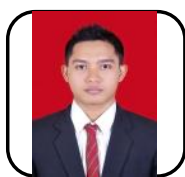

Rochman Jalil, Corresponding Author, Candidate Master of Management in Magister Management University of Sriwijaya, Indonesia

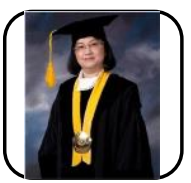

Prof. Hj. Badia Perizade MBA., Ph.D Lectures in Faculty Economic University of Sriwijaya, Indonesia. 
Effect of Training and Work Discipline on Employee Performance PT PLN (Persero) Power Plants Control Unit Keramasan

Hj. Marlina Widiyanti, S.E., S.H., M.M., Ph.D.

Lectures in Faculty Economic University of Sriwijaya, Indonesia. 